\title{
Isolation of Cellulose Degrading Fungi from Decaying Banana Pseudostem and Strelitzia alba
}

\author{
L. M. Legodi $(\mathbb{D}$, D. La Grange, E. L. Jansen van Rensburg, and I. Ncube \\ University of Limpopo Department of Biochemistry, Microbiology and Biotechnology, Private Bag X 1106, Sovenga, 0727, South Africa
}

Correspondence should be addressed to L. M. Legodi; 9731824@keyaka.ul.ac.za

Received 24 April 2019; Accepted 7 July 2019; Published 25 July 2019

Academic Editor: David Ballou

Copyright (C) 2019 L. M. Legodi et al. This is an open access article distributed under the Creative Commons Attribution License, which permits unrestricted use, distribution, and reproduction in any medium, provided the original work is properly cited.

Cellulases are a group of hydrolytic enzymes that break down cellulose to glucose units. These enzymes are used in the food, beverage, textile, pulp, and paper and the biofuel industries. The aim of this study was to isolate fungi from natural compost and produce cellulases in submerged fermentation $(\mathrm{SmF})$. Initial selection was based on the ability of the fungi to grow on agar containing Avicel followed by cellulase activity determination in the form of endoglucanase and total cellulase activity. Ten fungal isolates obtained from the screening process showed good endoglucanase activity on carboxymethyl cellulose-Congo Red agar plates. Six of the fungal isolates were selected based on high total cellulase activity and identified as belonging to the genera Trichoderma and Aspergillus. In SmF of synthetic media with an initial pH of 6.5 at $30^{\circ} \mathrm{C}$ Trichoderma longibrachiatum LMLSAUL 14-1 produced total cellulase activity of $8 \mathrm{FPU} / \mathrm{mL}$ and endoglucanase activity of $23 \mathrm{U} / \mathrm{mL}$ whilst Trichoderma harzianum LMLBP07 13-5 produced $6 \mathrm{FPU} / \mathrm{mL}$ and endoglucanase activity of $16 \mathrm{U} / \mathrm{mL}$. The produced levels of both cellulases and endoglucanase by Trichoderma species were higher than the levels for the Aspergillus fumigatus strains. Aspergillus fumigatus LMLPS 13-4 produced higher $\beta$-glucosidase $38 \mathrm{U} / \mathrm{mL}$ activity than Trichoderma species.

\section{Introduction}

Cellulose is a simple linear organic polymer of $\beta-1-4$ linked glucopyranose units with varying degrees of polymerization (DPs). In primary cell walls the DP range is $5000-7500$ glucopyranose units, whereas the DP in secondary cell walls is approximately 10000 and 15000 [1]. This polysaccharide is abundantly available in materials, such as agro-wastes, municipal wastes, and forest residues. The hydrolysis of cellulosic biomass through enzymatic reaction is a preferred method over chemical reaction due to the absence of sugar degradation in the enzymatic process [2].

Cellulases are enzymes with different specificities to catalyse the hydrolysis of glycosidic bonds within cellulose (Jecu, 2000; Khan et al., 2016). The enzymatic hydrolysis of cellulose involves exoglucanases (exo-1,4- $\beta$-glucanases, EC 3.2.1.91) endoglucanases (endo-1,4- $\beta$-glucanases, EC 3.2.1.4) and $\beta$ glucosidases ( $\beta$-D-glucoside glucohydrolase, EC 3.2.1.21) which exhibit high specificity for the $\beta-1.4$ glycosidic linkages (Jecu, 2000). Total cellulase is an activity involving the synergistic actions of the above enzymes that is measured using insoluble substrates such as the Whatman No. 1 filter paper, cotton linter, microcrystalline cellulose (Avicel), or bacterial cellulose [2].

The mechanism of action reveals that endoglucanases cleaves cellulose internally at the $\beta-1-4$ glycosidic linkage releasing oligosaccharide chains of different lengths, whereas exoglucanases cleaves the oligosaccharide chains from either the reducing or nonreducing ends to release disaccharides tri- and tetrasaccharides. $\beta$-Glucosidase cleaves the $\beta-1-4$ linkage in the disaccharide (cellobiose) to release glucose molecules and it can also hydrolyse very short chain $\beta$ 1,4 oligoglucosides up to cellohexaose, but the reaction rate decreases with chain length ([3, 4]; Saini et al., 2015).

Cellulases are increasingly demanded for use in the biofuel industry to produce bioethanol from cellulosic biomass. Technology for the utilization of cellulosic biomass for the production of bioethanol is progressing slowly due to high cost of cellulases production, the recalcitrant nature of cellulosic biomass, and inefficiency of available cellulases to release more fermentable sugars [5]. Research efforts have been undertaken to improve the catalytic efficiency of the known 
enzymes, identify new enzymes, and optimise enzyme mix preparations for cellulosic biomass hydrolysis [6]. Improving fungal hydrolytic activity and finding stable enzymes that are tolerant to extreme conditions have become priority [7].

Agricultural waste such as banana by-products provides an alternative to the use of food crops such as corn and wheat in ethanol production [8]. During the harvest of banana, waste generated including leaves, rachis, and pseudostem, all contain high levels of cellulose $[9,10]$. These cellulose rich materials are discarded and left to decay either in the plantation site or at a dumping site [10]. The decaying of plant material is facilitated by cellulolytic microorganisms. Hence this study aimed to isolate fungi that secrete cellulases with ability to hydrolyse cellulose in banana pseudostem to fermentable sugars for the bioethanol industry.

\section{Materials and Methods}

2.1. Sample Collection and Screening. Upper soil samples were collected in clean plastic bags from decomposed banana agrowaste (dumpsite and plantations) at the Tzaneen Allesbeeste farm, Limpopo, South Africa and from decomposed Strelitzia alba plant at the University of Limpopo campus, South Africa. Fungal isolation was done by serial dilution method. Threegram samples of soil from each site were suspended in $50 \mathrm{ml}$ sterile distilled water. A $100 \mu \mathrm{l}$ aliquot of soil suspension that had been diluted ten times was spread plated onto a selective Avicel agar medium (2\% Avicel, $1.5 \%$ agar, $5 \mathrm{ml}$ chloramphenicol $(50 \mathrm{mg} / \mathrm{ml})$ and $0.67 \%$ Yeast Nitrogen Base (YNB) without amino acids. The Avicel agar plates were incubated at $30^{\circ} \mathrm{C}$ until fungal growth was evident. The fungi were purified by hyphal tip method $[11,12]$. The fungal isolates were maintained on malt extract agar (30 g malt extract, $20 \mathrm{~g}$ dextrose, $3 \mathrm{~g}$ peptone, and $15 \mathrm{~g}$ agar) at $4^{\circ} \mathrm{C}$.

The enzymatic screening for cellulases was based on a carboxymethyl cellulose (CMC) plate assay whereby the agar medium was mixed with Congo Red (CR) dye [13]. The composition of the medium was $1 \%$ CMC, $1.5 \%$ agar, $0.67 \%$ YNB without amino acids, and $0.01 \%$ Congo Red. Ten fungal isolates obtained were cultured on CMC-CR agar and incubated at $30^{\circ} \mathrm{C}$ for $72-96 \mathrm{~h}$. As growth develops on CMCCR agar plate, the hydrolysis of CMC releases the bound CR dye. This is revealed by the appearance of pale yellow halo zone surrounding the fungal colony.

The second screening was based on cellulolytic hydrolysis of filter paper (total cellulase activity). Six fungal isolates were cultured in a synthetic medium described by Peixoto [14] and Avicel as the sole source of carbon. The synthetic media consisted of $2 \mathrm{~g} / \mathrm{l} \mathrm{K} 2 \mathrm{HPO}_{4}, 0.5 \mathrm{~g} / \mathrm{l} \mathrm{KCl}, 0.01 \mathrm{~g} / 1 \mathrm{FeSO}_{4} .7 \mathrm{H}_{2} \mathrm{O}$, $20 \mathrm{~g} / \mathrm{l}$ Avicel, $0.15 \mathrm{~g} / \mathrm{l} \quad \mathrm{MgSO}_{4} .7 \mathrm{H}_{2} \mathrm{O}, 7 \mathrm{~g} / \mathrm{KH}_{2} \mathrm{PO}_{4}, 1 \mathrm{~g} / \mathrm{l}$ $\left(\mathrm{NH}_{4}\right) \mathrm{SO}_{4}$, and $1 \mathrm{~g} / \mathrm{l}$ yeast extract. The $\mathrm{pH}$ of the medium was adjusted to 5.5 prior to sterilization. Inoculation was done by cutting approximately $0.5 \times 0.5 \mathrm{~cm}$ of fungal growth on agar medium and adding it into $100 \mathrm{ml}$ medium in $250 \mathrm{ml}$ Erlenmeyer flasks. All the flasks (Triplicates) were incubated at $30^{\circ} \mathrm{C}$ for 7 days, while shaking at $150 \mathrm{rpm}$. A $5 \mathrm{ml}$ sample was removed after every $24 \mathrm{~h}$ of incubation and used for determining total cellulase activity as expressed in filter paper units (FPU).
2.2. Molecular Identification of Fungal Isolates. Identification of fungi was based on the PCR amplification of the conserved nucleotide sequence of ribosomal internal transcribed spacer (ITS) of the gene coding for the 18S, 5.8S, and 28S rRNA [15]. Isolation and purification of fungal genomic DNA was performed by following the procedure outlined in the ZR Fungal/Bacterial DNA Kit ${ }^{\mathrm{TM}}$ (Zymo Research, Catalogue No. D6005).

The ITS target region (i.e., ITS-5.8S-ITS fragment) was amplified using EconoTaq ${ }^{\circledR}$ PLUS GREEN 2X Master Mix (Lucigen,) using the following primers, ITS1 $5^{\prime}$-TCCGTAGGTGAACCTGAGG- $3^{\prime}$ and ITS $45^{\prime}$-TCCTCCGCTTATTGATATGC- $3^{\prime}[15,16]$. The following PCR conditions were used: 35 cycles including an initial denaturation step at $95^{\circ} \mathrm{C}$ for 2 minutes. Subsequent denaturation was at $95^{\circ} \mathrm{C}, 30$ seconds, annealing at $50^{\circ} \mathrm{C}$ for 30 seconds, and extension at $72^{\circ} \mathrm{C}$ for 1 minute. A final extension at $72^{\circ} \mathrm{C}$ for 10 minutes was followed by holding at $4^{\circ} \mathrm{C}$. The PCR products were analysed on a $1 \%$ agarose gel.

DNA sequencing was done using ABI V3.1 Big dye according to manufacturer's instructions on the ABI 3500 XL Genetic Analyzer (Applied Biosystems, ThermoFisher Scientific Species were identified by searching databases using BLAST (http://www.ncbi.nlm.nih.gov/BLAST/).

\subsection{Effect of Initial Medium $p H$ and Incubation Temperature} on Cellulase Production. The effect of initial $\mathrm{pH}$ of the media on the production of cellulases was studied by adjusting the $\mathrm{pH}$ of the media using either $1 \mathrm{M} \mathrm{NaOH}$ or $1 \mathrm{M} \mathrm{HCl}$ solutions to $\mathrm{pH}$ values in the range of 4.5 to 7.0. The effect of temperature on the production of cellulase was investigated at 30,35 , and $40^{\circ} \mathrm{C}$ with $\mathrm{pH}$ being adjusted to 6.5 or 7.0 based on cellulase activity determined during $\mathrm{pH}$ studies. Inoculation and incubation conditions were maintained as described above, in secondary screening section. Samples of $5 \mathrm{~m} 1$ were harvested every $24 \mathrm{~h}$ of incubation and used for enzyme assays. Crude enzyme was prepared by centrifugation of harvested sample using a Beckman Coulter ${ }^{\circledR}$ microfuge $^{\circledR} 16$ centrifuge at $13000 \mathrm{rpm}$ for $10 \mathrm{~min}$ at room temperature.

2.4. Cellulase Activity Assay. The total cellulase activity was determined by filter paper assay (FPase) using Whatman No. 1 filter paper strip with a dimension of $1 \times 6.0 \mathrm{~cm}$ equivalent to $50 \mathrm{mg}$ of substrate according to Ghose (1987). At least two dilutions were made, one dilution that release slightly less than $2.0 \mathrm{mg}$ and the other dilution releasing more than $2.0 \mathrm{mg}$. The reaction mixture contained $1.0 \mathrm{ml}$ of $0.05 \mathrm{M}$ Na-citrate, $\mathrm{pH} 5.0$, filter paper strip, and $0.5 \mathrm{ml}$ of crude enzyme diluted accordingly. The mixture was incubated at $50^{\circ} \mathrm{C}$ for $1 \mathrm{~h}$. The released reducing sugar was estimated by addition of 3,5-dinitrosalicylic acid (DNS) with glucose as standard. The absorbance was read at $540 \mathrm{~nm}$ by using Beckman Coulter, DU ${ }^{\circledR} 720$ UV/Vis spectrophotometer. The assay was performed in triplicate including controls. Filter paper activity (FPU) is defined as 0.37 divided by the amount of enzyme required to liberate $2.0 \mathrm{mg}$ of glucose from filter paper strip $(\approx 50 \mathrm{mg})$ in $1 \mathrm{~h}$. 
TABLE 1: Fungal isolation and screening on Avicel and CMC-Congo Red agar.

\begin{tabular}{lcc}
\hline Sampling site & Isolate code no. & Isolate taxa \\
\hline $\begin{array}{l}\text { Banana plantation site, Allesbeeste farm, } \\
\text { Tzaneen }\end{array}$ & ${ }^{\mathrm{a}}$ LMLBP07 13-5 & Trichoderma harzianum \\
Decomposing banana pseudostem, & ${ }^{\mathrm{a}}$ LMLBP06 13-3 & Aspergillus fumigatus \\
Allesbeeste farm, Tzaneen & ${ }^{\mathrm{b}}$ LMLPS 13-1 & Aspergillus fumigatus \\
$\begin{array}{l}\text { Banana dumpsite, Allesbeeste farm, } \\
\text { Tzaneen }\end{array}$ & ${ }^{\mathrm{b}}$ LMLPS 13-4 & Aspergillus fumigatus \\
$\begin{array}{l}\text { Decomposing Strelizia alba, University of } \\
\text { Limpopo }\end{array}$ & ${ }^{\mathrm{c}}$ LMLBS02 13-2 & Aspergillus fumigatus \\
\hline
\end{tabular}

${ }^{\mathrm{a}} \mathrm{BP}$ refers to banana plantation site; ${ }^{\mathrm{b}} \mathrm{PS}$ refers to Pseudostem; ${ }^{\mathrm{c}} \mathrm{BS}$ refers to banana dumpsite outside plantation; ${ }^{\mathrm{d}}$ SAUL refers to Strelitzia alba at University of Limpopo

2.5. Endoglucanase Assay. Endoglucanase activity in the culture supernatant was determined according to the method described by Ghose (1987). The reaction mixture contained $0.5 \mathrm{ml}$ of $1 \% \mathrm{CMC}$ in $0.05 \mathrm{M}$ Na-acetate buffer, $\mathrm{pH} 5.0$, and $0.5 \mathrm{ml}$ of appropriately diluted crude enzyme. The mixture was incubated at $50^{\circ} \mathrm{C}$ for $30 \mathrm{~min}$ and the released reducing sugar was estimated as indicated in the assay for total activity above. One unit of endoglucanase activity was defined as the amount of enzyme liberating one $\mu$ mole of reducing sugar from $\mathrm{CMC}$ under the assay conditions.

2.6. $\beta$-Glucosidase Assay. $\beta$-Glucosidase activity was determined according to the method described by Herr [17]. The reaction mixture contained $0.2 \mathrm{ml}$ of $0.01 \mathrm{M} \rho$-nitrophenyl $\beta$-D-glucopyranoside ( $\mathrm{pNPG}$ ) in $0.05 \mathrm{M}$ citrate buffer $\mathrm{pH}$ 4.8 and $0.2 \mathrm{ml}$ of appropriately diluted enzyme solution. The substrate control contained $0.4 \mathrm{ml}$ of $0.01 \mathrm{M}$ pNPG prepared in $0.05 \mathrm{M}$ citrate buffer at $\mathrm{pH} 4.8$. The mixtures were incubated at $50^{\circ} \mathrm{C}$ for $30 \mathrm{~min}$. The reaction was stopped by adding $4 \mathrm{ml}$ of a $50 \mathrm{mM} \mathrm{NaOH}$-Glycine buffer, $\mathrm{pH}$ 10.6. The activity of the enzyme, indicated by the release of $\rho$-nitrophenol, was determined at $420 \mathrm{~nm}$ using Beckman Coulter, DU ${ }^{\circledR} 720 \mathrm{UV} / \mathrm{Vis}$ spectrophotometer $[18,19]$. One unit of $\beta$-glucosidase activity was defined as the amount of enzyme liberating one $\mu$ mole of $\rho$-nitrophenol under the assay conditions.

2.7. Calculations of Enzyme Activity. Cellulase activity was determined by filter paper assay using Whatman No. 1 according to Ghose (1987).

\subsubsection{Cellulases (FPase).}

$$
\operatorname{FPA}\left(\frac{\mathrm{FPU}}{\mathrm{mL}}\right)=\frac{0.37}{[\mathrm{Enz}]}
$$

where [Enz] is the concentration of enzyme that releases $2.0 \mathrm{mg}$ of glucose from filter paper in 60 minutes.

2.7.2. Endoglucanase (CMCase) and $\beta$-Glucosidase. To estimate the activities of either endoglucanase and/or $\beta$ glucosidase based on the released reducing sugars or $\rho$ nitrophenol, the following equation was used [20]:

$$
\beta \text { - glucosidase or CMCase }\left(\frac{\mathrm{U}}{\mathrm{mL}}\right)=\frac{\Delta \mathrm{E} \times \mathrm{Vf} \times \mathrm{Df}}{\varepsilon \times \Delta \mathrm{t} \times \mathrm{Venz}},
$$

whereby $\Delta \mathrm{E}$ is absorbance value at $540 \mathrm{~nm}$, Vf is final volume, $\varepsilon$ is extinction coefficient of glucose (slope), $\Delta \mathrm{t}$ is incubation time, Venz is volume of crude enzyme, and DF is dilution factor (if applicable).

\section{Results}

Ten fungal isolates were obtained based on their ability to grow on Avicel as sole source of carbon on solid media. These fungal isolates were further screened for endoglucanase activity by culturing on CMC-CR agar plates at $30^{\circ} \mathrm{C}$ for 72 $96 \mathrm{~h}$. The results revealed that all the isolated fungi were able to grow and secrete endoglucanase which hydrolysed CMC bound to CR dye. This was revealed by appearance of paleyellow "halo zone" around the fungal growth or colony and it was indication of endoglucanase activity or CMC hydrolysis. However, only six fungal isolates indicated larger halo zones around growth. These six fungal isolates were subsequently identified using ITS sequencing. The identification of the selected six isolates revealed two different genera, namely, Trichoderma and Aspergillus (Table 1). The Trichoderma species were T. longibrachiatum and T. harzianum and the Aspergillus species were A. fumigatus. The six fungal isolates were further evaluated for cellulase production in submerged fermentation.

A quantitative evaluation of cellulase production by the selected fungi (Table 1) was carried out in submerged fermentation using Avicel as a substrate at an initial $\mathrm{pH}$ of 5.5 at $30^{\circ} \mathrm{C}$. The production levels of cellulases were measured by the activity of the enzymes under specified conditions. Maximum cellulase activity was observed after $96 \mathrm{~h}$ for all the fungal strains (Figure 1). T. longibrachiatum LMLSAUL 141 produced 4.1 FPU/ml followed by T. harzianum LMLBP07 13-5 with activity of 3.1 FPU/ml, A. fumigatus LMLPS 13-4 with activity of 2.1 FPU/ml, A. fumigatus LMLPS 13-1 with activity of 1.9 FPU/ml, A. fumigatus LMLBS02 13-2 activity of $1.7 \mathrm{FPU} / \mathrm{ml}$, and A. fumigatus LMLBP06 13-3 activity of 1.6 $\mathrm{FPU} / \mathrm{ml}$.

The influence of $\mathrm{pH}$ on the production of cellulase was assessed for the six fungal strains at $30^{\circ} \mathrm{C}$ (Figure 2). Maximum cellulase activity was detected for all fungal isolates 


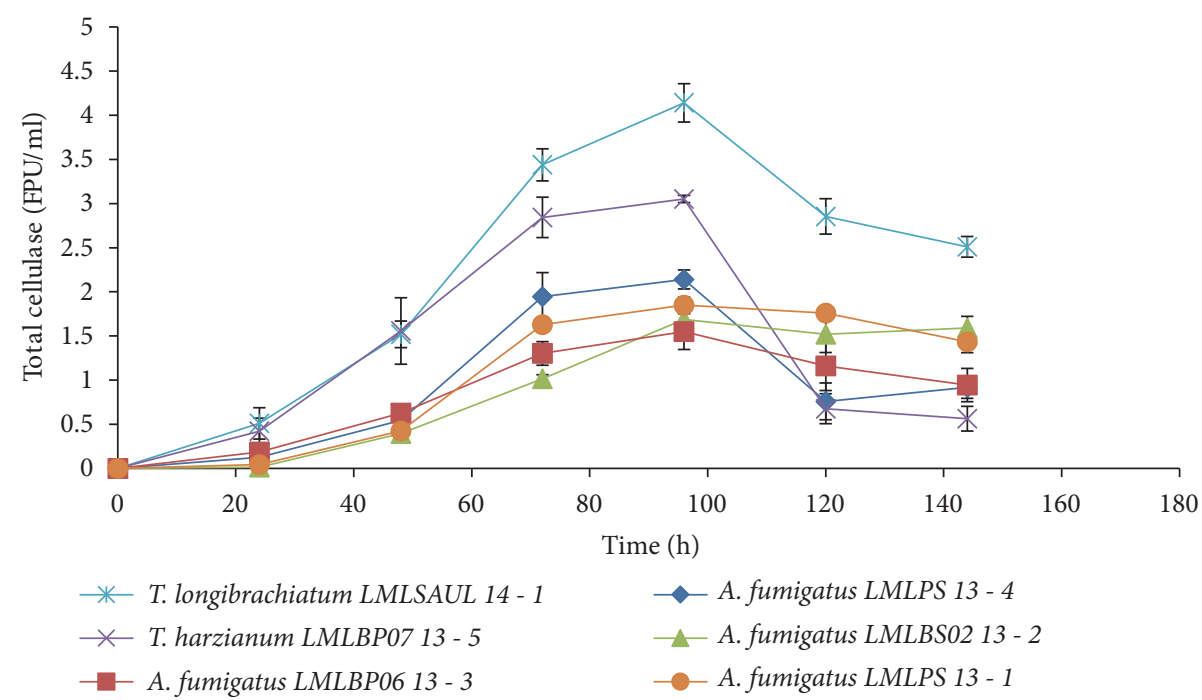

Figure 1: Time course for cellulase production by isolated fungal strains at $30^{\circ} \mathrm{C}$ and initial $\mathrm{pH} 5.5$.

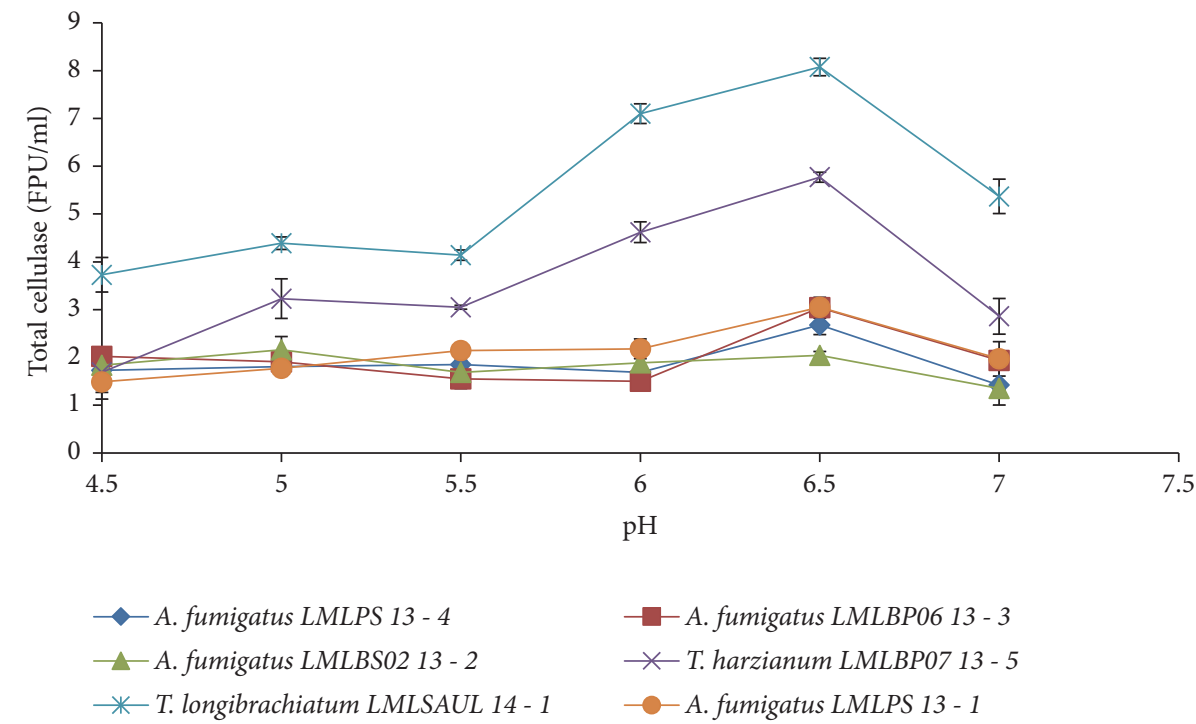

Figure 2: The effect of initial medium $\mathrm{pH}$ on the production of cellulases by isolated fungi at $30^{\circ} \mathrm{C}$.

when the initial $\mathrm{pH}$ of the medium was 6.5 (Figure 2). The Trichoderma longibrachiatum LMLSAUL 14-1 strain produced the highest total cellulase activity of $8.1 \mathrm{FPU} / \mathrm{ml}$. This was followed by T. harzianum LMLBP07 13-5 with activity of 5.8 FPU/ml. A. fumigatus LMLBP06 13-3 and A. fumigatus LMLPS 13-1 produced maximum cellulase activity of 3.1 $\mathrm{FPU} / \mathrm{ml}$ with the lowest cellulase activity of $2.0 \mathrm{FPU} / \mathrm{ml}$ being produced by A. fumigatus LMLPS 13-4.

The production of endoglucanase activity was highest at $\mathrm{pH} 6.5$ for all the fungal strains (Figure 3). T. longibrachiatum LMLSAUL $14-1$ and T. harzianum LMLBP07 13-5 produced activities of $23.0 \mathrm{U} / \mathrm{ml}$ and $16.0 \mathrm{U} / \mathrm{ml}$, respectively, whereas A. fumigatus LMLPS 13-1, LMLBS02 13-2, and LMLBP06 133 produced amounts of $14.0 \mathrm{U} / \mathrm{ml}$. The lowest activity of 12.1 $\mathrm{U} / \mathrm{ml}$ was noted for $A$. fumigatus LMLPS 13-4.
The levels of $\beta$-glucosidase produced with respect to initial medium $\mathrm{pH}$ differed between the fungal strains. A. fumigatus LMLPS 13-4 and A. fumigatus LMLBS02 13-2 produced higher activities of $38.0 \mathrm{U} / \mathrm{ml}$ and $34.1 \mathrm{U} / \mathrm{ml}$ at $\mathrm{pH} 7.0$, respectively, compared to the other isolates tested (Figure 4). Some fungi were able to secrete higher $\beta$-glucosidase at various $\mathrm{pH}$ values. T. harzianum LMLBP07 13-5 produced $\beta$-glucosidase activity of $25.7 \mathrm{U} / \mathrm{ml}$ over a $\mathrm{pH}$ range of 6 - 7.0 and A. fumigatus LMLPS $13-1$ produced $\beta$-glucosidase activity of $23.5 \mathrm{U} / \mathrm{ml}$ over a $\mathrm{pH}$ range of $6.5-7.0$ (Figure 4 ). The lowest $\beta$-glucosidase activity produced was $20.6 \mathrm{U} / \mathrm{ml}$ by T. longibrachiatum LMLSAUL $14-1$.

The production of cellulases with respect to changes in incubation temperature was also investigated at initial medium $\mathrm{pH}$ of 6.5 and 7.0 (Figures 5 and 6). These $\mathrm{pH}$ values 


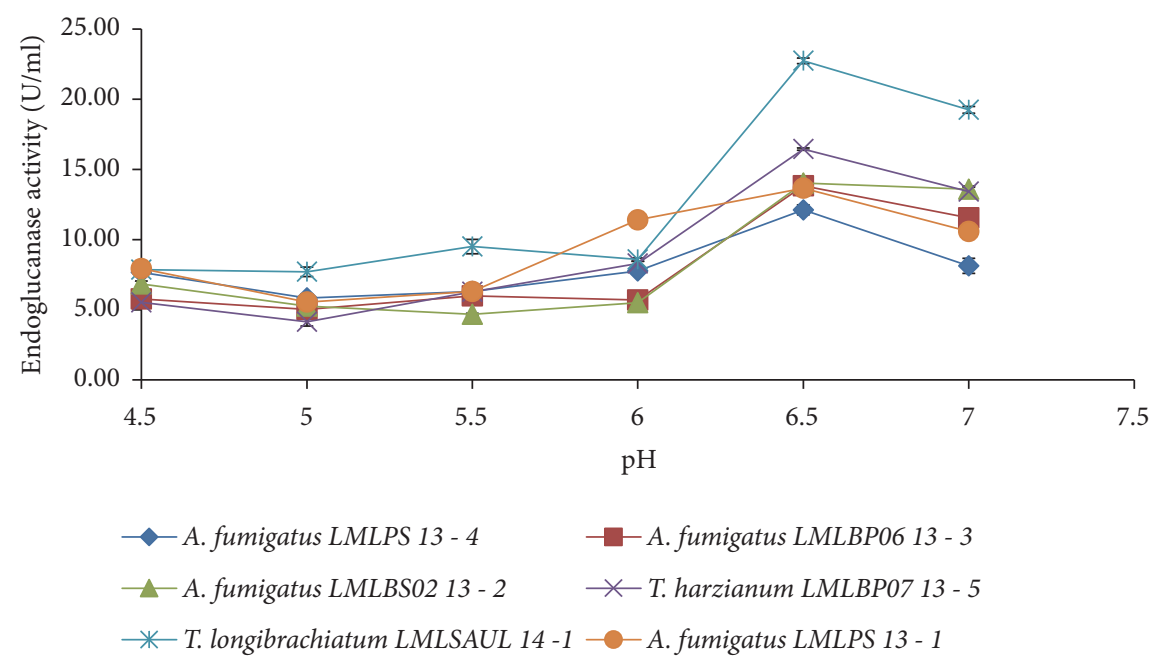

FIgURE 3: The effect of initial medium $\mathrm{pH}$ on the production of endoglucanases by the isolated fungal strains at $30^{\circ} \mathrm{C}$.

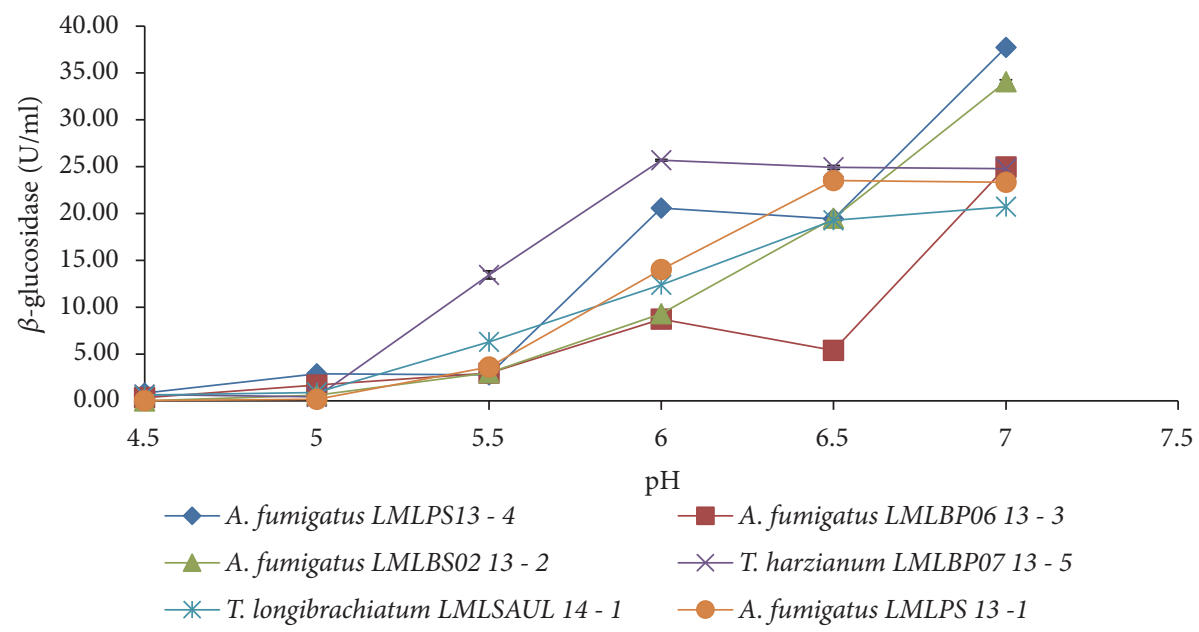

FIgURE 4: The effect of initial medium $\mathrm{pH}$ on the production of $\beta$-glucosidase by the isolated fungi at $30^{\circ} \mathrm{C}$.

have shown to favour production of $\beta$-glucosidase by species of Aspergillus and Trichoderma. At initial medium $\mathrm{pH}$ of 6.5 an increase in growth temperature led to a decrease in the level of total cellulase activity for T. longibrachiatum LMLUL $14-1$ at $35^{\circ} \mathrm{C}$ (Figure 5). The A. fumigatus strains were able to produce cellulase at both 30 and $35^{\circ} \mathrm{C}$, with the exception of T. harzianum LMLUL 13-5. Cellulase activity in A. fumigatus LMLUL 13-1 increased by 1.8 -fold at $35^{\circ} \mathrm{C}$ (Figure 5). Increasing the incubation temperature to $40^{\circ} \mathrm{C}$ drastically reduced the cellulase production for T. longibrachiatum LMLUL 141, A. fumigatus LMLUL 13-1, and A. fumigatus LMLUL 13-3 (Figure 5). Generally, most fungal species showed cellulase activity levels decreasing as the temperature increased to $40^{\circ} \mathrm{C}$.

At initial medium $\mathrm{pH}$ of 7.0 and a temperature of $30^{\circ} \mathrm{C}$ favoured high production of cellulase by $T$. harzianum LMLBP07 14-5, T. longibrachiatum LMLUL 14-1, and A. fumigatus LMLBS02 13-2 (Figure 6).

The cellulase production by A. fumigatus LMLPS 13-1, A. fumigatus LMLBP06 13-3, and A. fumigatus LMLPS 13-4 improved at $35^{\circ} \mathrm{C}$, irrespective of initial $\mathrm{pH}$ tested (Figures 5 and 6). At production temperature $40^{\circ} \mathrm{C}$, the production of cellulases was reduced for all strains tested. All the Trichoderma and Aspergillus strains produced more endoglucanases at $30^{\circ} \mathrm{C}$ with both initial medium $\mathrm{pH}$ of 6.5 and 7.0 (Figures 7 and 8), but initial medium $\mathrm{pH}$ of 6.5 favoured more enzyme production. An increase in temperature to $35^{\circ} \mathrm{C}$ and $40^{\circ} \mathrm{C}$ resulted in a 2 -fold decrease of the endoglucanase activity in all fungal species (Figure 7).

In an experiment with initial medium $\mathrm{pH} 7.0$ a greater improvement in the production of endoglucanases was seen at $35^{\circ} \mathrm{C}$ (Figure 8). T. harzianum LMLBP07 13-5 produced 2 -fold higher endoglucanase activity at initial medium $\mathrm{pH}$ of 7.0, while other fungal species attained slight increases (Figure 8).

At both initial medium $\mathrm{pH}$ of 6.5 and 7.0 higher temperatures caused a reduction in endoglucanase activity and severe reduction occurred at $40^{\circ} \mathrm{C}$ as illustrated in Figures 7 and 8 .

The production of $\beta$-glucosidase at an initial $\mathrm{pH}$ of 6.5 and 7.0 was dependent on the fungal species and production 


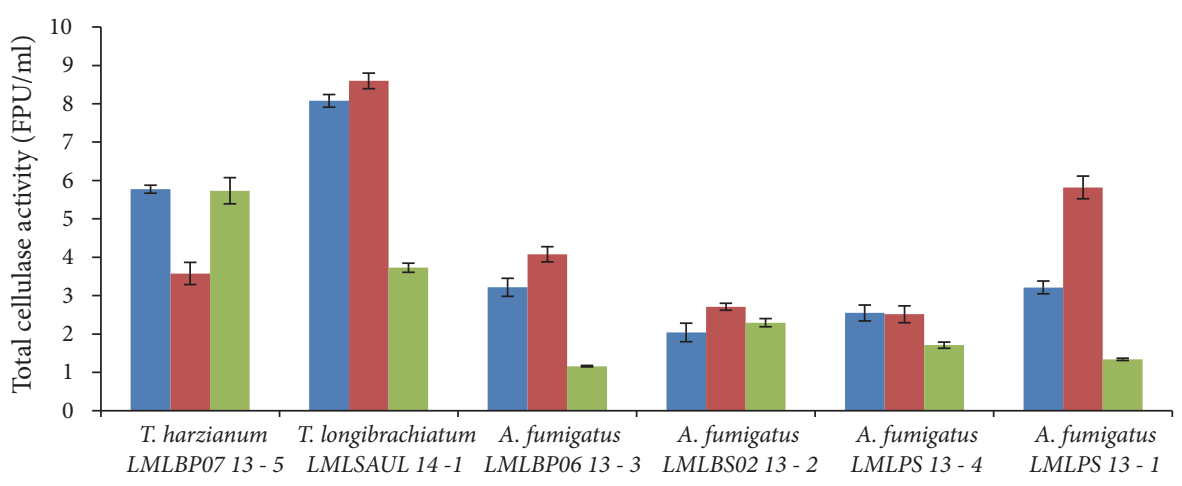

Fungal isolates

$$
\begin{aligned}
& \text { Fpase } 30^{\circ} \mathrm{C} \\
& \text { Fpase } 35^{\circ} \mathrm{C} \\
& \text { Fpase } 40^{\circ} \mathrm{C}
\end{aligned}
$$

FIGURE 5: Effect of incubation temperature on the production of cellulase (total cellulase activity) by fungal strains at initial medium pH 6.5 .

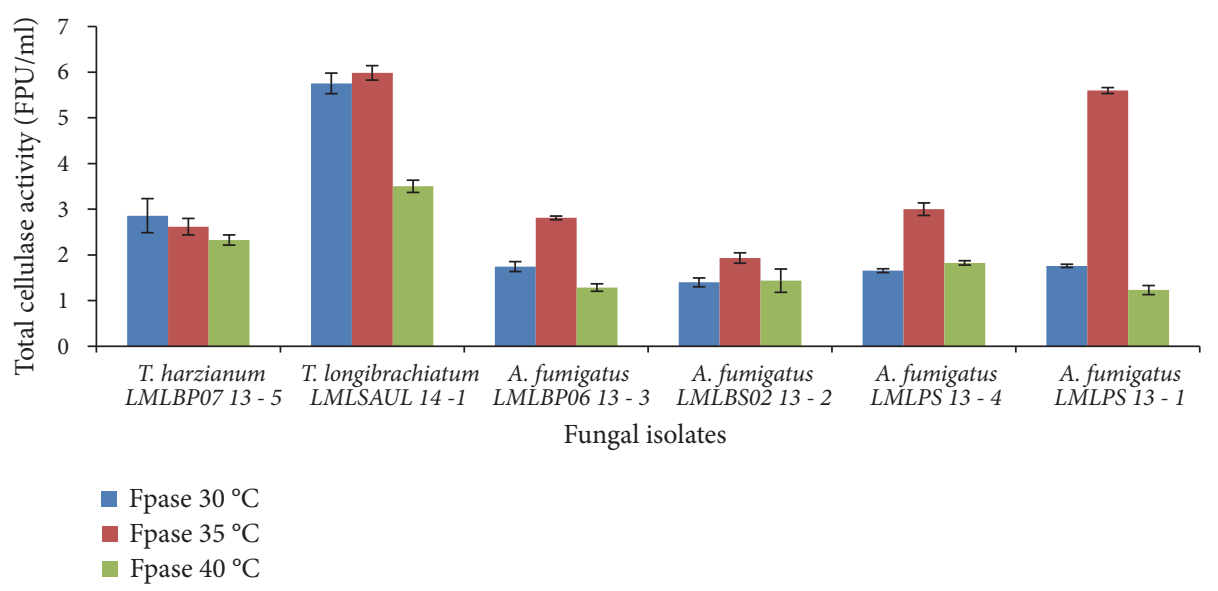

FIGURE 6: Effect of incubation temperature on the production of cellulases (total cellulase activity) by fungal strains at initial medium pH 7.0.

temperature. In a medium with an initial $\mathrm{pH}$ of 6.5 , only A. fumigatus LMLPS 13-1 and T. harzianum LMLBP07 13-5 produced high levels of $\beta$-glucosidase activity $24.0 \mathrm{U} / \mathrm{ml}$ and $25.0 \mathrm{U} / \mathrm{ml}$, respectively at $30^{\circ} \mathrm{C}$. An increase in temperature from 30 to $40^{\circ} \mathrm{C}$ led to improved production of $\beta$-glucosidase by some fungal species. For instance, $A$. fumigatus LMLBP06 13-3 showed 5-fold increase, i.e., from 5.4 to $25.4 \mathrm{U} / \mathrm{ml}$ of $\beta$-glucosidase activity at $40^{\circ} \mathrm{C}$ and 5.2 -fold increase of $\beta$ glucosidase at $35^{\circ} \mathrm{C}$ (Figure 9).

The production of $\beta$-glucosidase by $T$. harzianum LMLBP07 13-5 was optimal between 35 and $40^{\circ} \mathrm{C}$, whilst T. longibrachiatum LMLSAUL $14-1$ produced $\beta$-glucosidase optimally at $40^{\circ} \mathrm{C}$. A. fumigatus LMLPS $13-4$ attained maximum $\beta$-glucosidase activity at $30^{\circ} \mathrm{C}$ (Figure 9). Generally, at $40^{\circ} \mathrm{C}$ the production of $\beta$-glucosidase by all fungal species was much higher than at $30^{\circ} \mathrm{C}$ with the exception of $A$. fumigatus LMLPS 13-4. In a medium with initial $\mathrm{pH}$ 7.0, an increase in temperature led to improvement in the production of $\beta$-glucosidase (Figure 10). A maximum level of $\beta$ glucosidase level was attained at $35^{\circ} \mathrm{C}$ with $T$. longibrachiatum LMLSAUL 14-1 and T. harzianum LMLBP07 13-5 showing 1.55-fold increase and 1.13-fold increase, respectively. $A$. fumigatus LMLPS 13-4 and A. fumigatus LMLPS 13-1 also showed an increase of $\beta$-glucosidase activity at $35^{\circ} \mathrm{C}(1.76$ fold and 1.6-fold, respectively). A. fumigatus LMLBP06 13-3 showed a proportional increase of 1.27 -fold with maximum $\beta$-glucosidase produced at $40^{\circ} \mathrm{C}$. Conversely, $40^{\circ} \mathrm{C}$ led to a 1.26 -fold decrease of $\beta$-glucosidase produced by $A$. fumigatus LMLBS02 13 - 2 (Figure 10).

Generally, $\beta$-glucosidase activity was the highest at $35^{\circ} \mathrm{C}$ and $\mathrm{pH} 7.0$ for all strains tested.

\section{Discussion}

4.1. Fungal Screening. Fungi and bacteria are associated with soil and decaying plant materials. In nature, fungi colonise the plant debris and in symbiotic relationship with other microorganisms, they secrete an assortment of proteins and a complex of hydrolytic enzymes to hydrolyse plant polysaccharides for their survival. However, not all the microorganisms are able to secrete significant amount of hydrolytic enzymes for biotechnological applications. Hence, 
Fungal isolates

andoglucanase $30^{\circ} \mathrm{C}$

- Endoglucanase $35^{\circ} \mathrm{C}$

- Endoglucanase $40^{\circ} \mathrm{C}$

FIGURE 7: Effect of incubation temperature on the production of endoglucanase by fungal strains at initial medium pH 6.5.

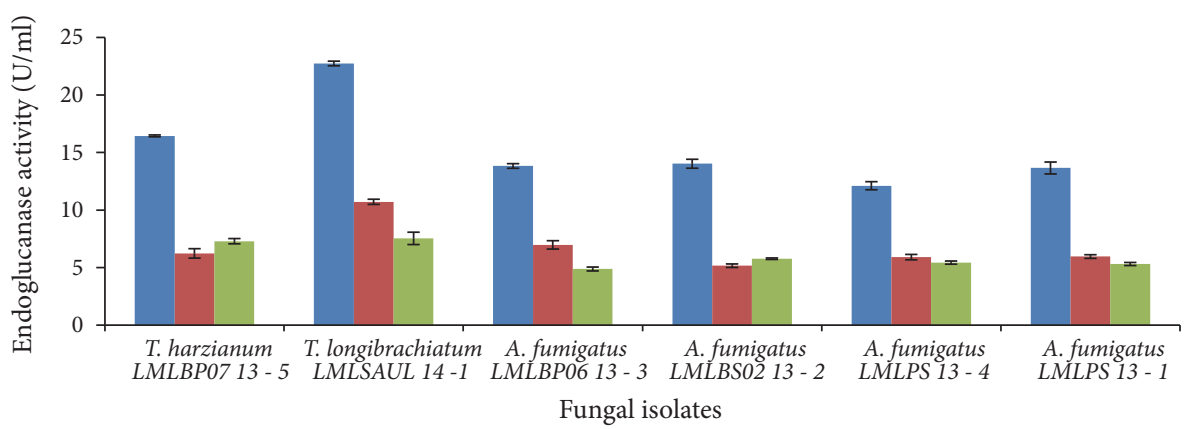

Endoglucanase $30^{\circ} \mathrm{C}$

- Endoglucanase $35^{\circ} \mathrm{C}$

Endoglucanase $40^{\circ} \mathrm{C}$

FIGURE 8: Effect of incubation temperature on the production of endoglucanase by fungal strains at initial medium pH 7.0.

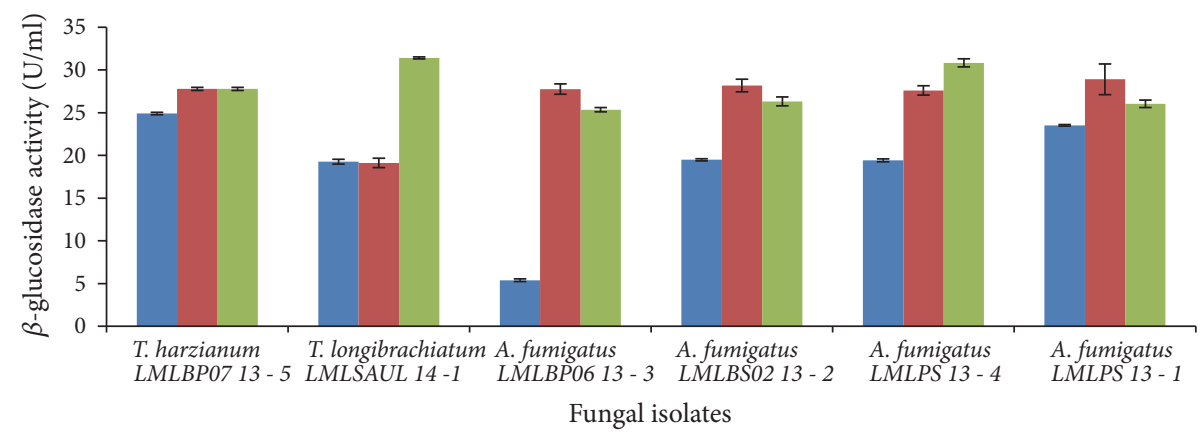

B-glucosidase $30^{\circ} \mathrm{C}$
B-glucosidase $35^{\circ} \mathrm{C}$
B-glucosidase $40^{\circ} \mathrm{C}$

FIGURE 9: Effect of incubation temperature on the production of $\beta$-glucosidase by fungal strains at initial medium $\mathrm{pH} 6.5$.

there is a need to screen and select hypersecreting hydrolytic enzymes. In this study, three different methods for screening for cellulolytic activity, (1) microbial growth on cellulose agar, (2) clearing of cellulose in agar, and (3) reducing sugar production (or glucose), were performed. Growth on cellulose containing agar was useful for isolation of cellulolytic fungal strains. Ten fungal strains were selected based on fast and abundant growth on Avicel agar plates. Several authors have also reported the use of microcrystalline cellulose to screen for cellulase producing microorganisms [21-23]. CMC-CR 


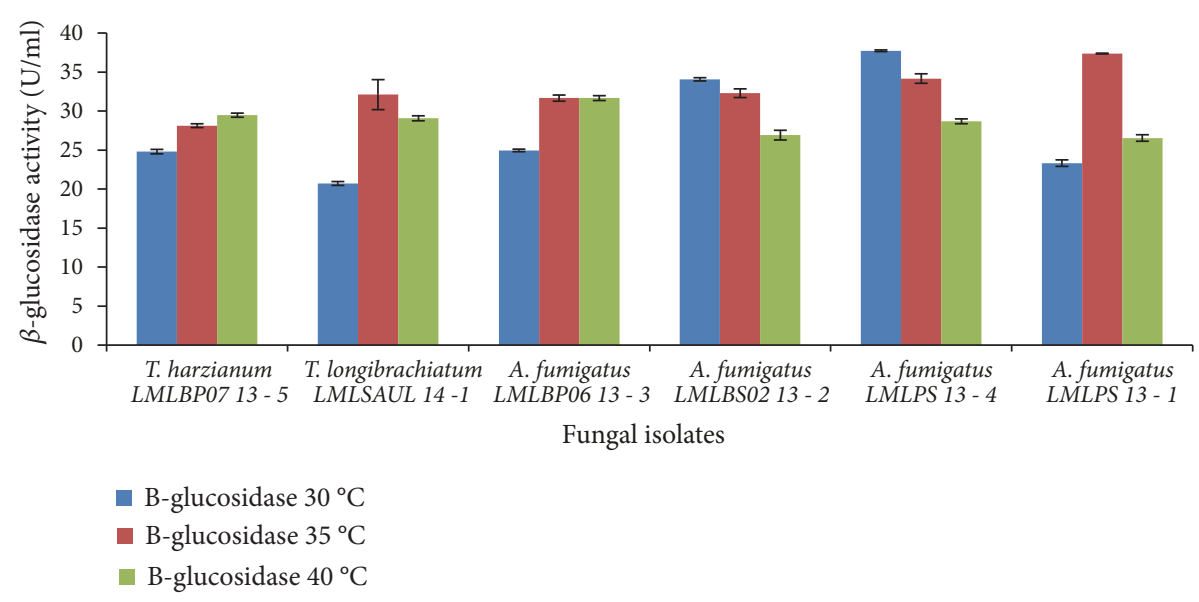

FIGURE 10: Effect of incubation temperature on the production of $\beta$-glucosidase by fungal strains at initial pH 7.0.

(0.01\%) agar plate has been used to detect endoglucanase activity as indicated by the presence of a pale yellow zone around the colony. According to Yoon et al. [13], the plate screening methods with dye coupled substrates provides a relatively straight forward and easy tool for specific detection of fungi that produce endoglucanase. Larger halos are the results of higher enzyme activity [2]. However, at high CR dye concentrations, fungal growth is suppressed.

4.2. Fungal Identification. The application of rDNA genes for identification of fungal species is based on the detection of conserved sequences in 5.8S rDNA and 28S rDNA that enables the amplification of the ITS2 region between them [24]. The identification of the fungal species based on the amplification of the ribosomal ITS region of the ribosomal DNA revealed that the organisms are A. fumigatus strains, T. harzianum, and T. longibrachiatum. The ITS regions are regarded as primary DNA barcode for the fungal kingdom and exhibit high reliability [25].

4.3. Cellulases Production and Optimisation. Subsequent to screening is process optimisation with various factors such as nutrient requirements, temperature, $\mathrm{pH}$, and agitation speed. been investigated (Gautam et al., 2010; [26]). In this study, the effect of initial $\mathrm{pH}$ and temperatures on the production levels of cellulase were investigated. Fungal strains belonging to Trichoderma and Aspergillus exhibited the potential to produce cellulase over a $\mathrm{pH}$ 4.5-7.0 and temperature (3040) range, although the cellulase production levels varied from one fungal strain to another under the conditions used. It has been reported that expression of fungal genes is regulated by extracellular $\mathrm{pH}$ and many fungi exhibit growth and enzyme secretion over a wide $\mathrm{pH}$ range [27]. Temperature also influences microbial growth and enzyme production $[20,28]$ and an optimal environment conducive to the production of cellulase will also be influenced by media nutritional composition [26].

The initial $\mathrm{pH}$ of 4.5-5.5 drastically reduced the levels of cellulases and endoglucanases produced by all strains. This implied that acidity of the medium possibly affected fungal growth and metabolism. Acidic medium $\mathrm{pH}$ effect on the production of cellulases by Trichoderma and Aspergillus was also reported by Gautam et al. [29] and Delabona et al. [23]. Contrary to these results, other authors reported such acidic condition to be favourable for production of cellulases [22, 30-34]. Our results showed that a less acidic medium with a $\mathrm{pH} 5.5$ and above favoured the production of cellulases by all Trichoderma and Aspergillus strains with optimum production occurring at a $\mathrm{pH}$ of 6.5 . Beyond $\mathrm{pH}$ 6.5 a drastic decrease in cellulases levels was observed. Gilna \& Khaleel [35] and Gautam et al. ([29]; 2010) also reported maximum production of cellulases at $\mathrm{pH}$ 6.5. Aboul-Fotouh et al. [36] reported maximum production of cellulases by Aspergillus niger at initial medium $\mathrm{pH}$ of 6 when cultured on $10 \%$ rice straw. Other findings by Ncube et al. [37] showed no significant differences in the production of endoglucanases by A. niger FGSCA 733 over a $\mathrm{pH}$ range of 3-7. These findings illustrate that an optimum $\mathrm{pH}$ for maximum production of cellulase is dependent on fungal species and to some extent on the particular strain evaluated.

There was effect of temperature on the production of cellulases. The production of cellulases decreased with increasing temperature. At $40^{\circ} \mathrm{C}$ a significant reduction in endoglucanases activity was observed in all strains tested (Figures 8 and 9). On the contrary, Ncube et al. [37] reported maximum endoglucanase activity at $40^{\circ} \mathrm{C}$ by $A$. niger FGSCA 733. Other studies reported optimal cellulase and endoglucanase production at $45^{\circ} \mathrm{C}$ [29] and $60^{\circ} \mathrm{C}[22$, 38]. A temperature of $40^{\circ} \mathrm{C}$ did not significantly affect $\beta$ glucosidase production (Figures 9 and 10). Leghlili et al. (2013) reported the production of cellulases, endoglucanases, and $\beta$-glucosidase T. longibrachiatum (GHL) at both $30^{\circ} \mathrm{C}$ and $35^{\circ} \mathrm{C}$, with higher production levels obtained at $35^{\circ} \mathrm{C}$. Other authors reported maximum production levels of $\beta$ glucosidase by $T$. longibrachiatum at $35^{\circ} \mathrm{C}$ [39] and A. niger MS82 at $25^{\circ} \mathrm{C}$. [30]. Aspergillus niger MS82 also produced sufficient endoglucanases at $30^{\circ} \mathrm{C}$ and $35^{\circ} \mathrm{C}$ in acidic initial medium pH 4.0 [30].

These discrepancies with regard to the optimum initial $\mathrm{pH}$ and production temperature on the levels of cellulases as 
measured by filter paper activity (FPU/ml) can be attributed to genetic make-up of the fungal strains as a result of adaptations to different habitats. Furthermore, our reported high levels of cellulases, endoglucanases, and low level of $\beta$ glucosidase by the Trichoderma isolates and vice versa high levels of $\beta$-glucosidase by A. fumigatus are in agreement with the reported levels of these fungal species by Stewart and Parry [38].

\section{Conclusion}

In conclusion, all the Trichoderma and Aspergillus strains produced substantial levels of all the three enzymes (i.e., exoglucanase, endoglucanase, and $\beta$-glucosidase) required for complete hydrolysis of cellulosic material. Trichoderma strains produced higher cellulases and endoglucanases levels while A. fumigatus strains produced higher $\beta$-glucosidase levels. The production of all the cellulases components seemed to be strongly influenced by the interactive effect of initial $\mathrm{pH}$ and incubation temperature on the microorganisms. Hence, the observed maximum production of cellulases by the fungi depended on the chosen initial $\mathrm{pH}$ of the medium and incubation temperature. The cellulases produced by these fungal strains will be assessed for efficiency in hydrolysing agricultural lignocellulose wastes, including banana pseudostem for the production of bioethanol.

\section{Data Availability}

The experimental data used to support the findings of this study are available from the corresponding author upon request.

\section{Conflicts of Interest}

The authors declare that they have no conflicts of interest.

\section{Acknowledgments}

The authors are grateful to the National Research Foundation (NRF) and the Flemish Inter-University Council (VLIRUOS) for the financial support towards the research.

\section{References}

[1] A. C. O'Sullivan, "Cellulose: the structure slowly unravels," Cellulose, vol. 4, no. 3, pp. 173-207, 1997.

[2] Y.-H. P. Zhang, M. E. Himmel, and J. R. Mielenz, "Outlook for cellulase improvement: screening and selection strategies," Biotechnology Advances, vol. 24, no. 5, pp. 452-481, 2006.

[3] P. Beguin and J. P. Aubert, "The biological degradation of cellulose," FEMS Microbiology Review, vol. 13, pp. 25-28, 1994.

[4] M. K. Bhat and S. Bhat, "Cellulose degrading enzymes and their potential industrial applications," Biotechnology Advances, vol. 15, no. 3-4, pp. 583-620, 1997.

[5] J. Zhuang, M. A. Marchant, S. E. Nokes, and H. J. Strobel, "Economic analysis of cellulase production methods for bioethanol," Applied Engineering in Agriculture, vol. 23, no. 5, pp. 679-687, 2007.
[6] S. T. Merino and J. Cherry, "Progress and challenges in enzyme development for biomass utilization," Advances in Biochemical Engineering/Biotechnology, vol. 108, pp. 95-120, 2007.

[7] M. Dashtban, H. Schraft, and W. Qin, "Fungal bioconversion of lignocellulosic residues; Opportunities \& perspectives," International Journal of Biological Sciences, vol. 5, no. 6, pp. 578-595, 2009.

[8] B. S. Padam, H. S. Tin, F. Y. Chye, and M. I. Abdullah, "Banana by-products: an under-utilized renewable food biomass with great potential," Journal of Food Science and Technology, vol. 51, no. 12, pp. 3527-3545, 2014.

[9] H. P. S. Abdul Khalil, M. S. Alwani, and A. K. M. Omar, "Chemical composition, anatomy, lignin distribution and cell wall structure of Malaysian plant waste fibres," BioResources, vol. 1, no. 2, pp. 220-232, 2006.

[10] K. Li, S. Fu, H. Zhan, Y. Zhan, and L. A. Lucia, "Analysis of the chemical composition and morphological structure of banana pseudostem," Bioresources, vol. 5, no. 2, pp. 576-585, 2010.

[11] K. Ibatsam, S. H. Muhammad, M. Sobia, and M. Irum, "Isolation and screening of highly cellulolytic filamentous fungi," Journal of Applied Science and Environmental Management, vol. 16, no. 3, pp. 223-226, 2012.

[12] G. Núňez-Trujillo, R. Cabrera, A. Cosoveanu, T. T. Martin, C. Gimenez, and G. Núňez-Trujillo, "Survey of banana endophytic fungi isolated in artificial culture media from an applied viewpoint," Journal of Horticulture, Forestry and Biotechnology, vol. 17, no. 2, pp. 22-25, 2013.

[13] J. H. Yoon, J. E. Park, D. Y. Suh, S. B. Hong, S. J. Ko, and S. H. Kim, "Comparison of dyes for easy detection of extracellular cellulases in fungi," Mycobiology, vol. 35, no. 1, pp. 21-24, 2007.

[14] A. B. Peixoto, Study of the production of enzymes and gums by wild yeasts collected in various regions of Brazil [M.S. Thesis], Faculty of Food Engineering, University of Campinas, Campinas, Brazil, 2006.

[15] T. J. White, T. Bruns, S. Lee, and J. Taylor, "Amplification and direct sequencing of fungal ribosomal RNA genes for phylogenetics," in PCR Protocols: A Guide to Methods And Applications, M. A. Innis, D. H. Gelfand, J. J. Sninsky et al., Eds., pp. 315-322, Academic Press, Inc, New York, NY, USA, 1990.

[16] B. Benoliel, F. A. Gonçalves Torres, and L. M. P. de Moraes, "A novel promising Trichoderma harzianum strain for the production of a cellulolytic complex using sugarcane bagasse in natura," SpringerPlus, vol. 2, p. 256, 2013.

[17] D. Herr, "Secretion of cellulase and $\beta$-glucosidase byTrichoderma viride ITCC-1433 in submerged culture on different substrates," Biotechnology and Bioengineering, vol. 21, no. 8, pp. 1361-1371, 1979.

[18] A. S. Lakshmi and G. Narasimha, "Production of cellulases by fungal cultures isolated from forest litter soil," Annals of Forest Research, vol. 55, no. 1, pp. 85-92, 2012.

[19] X. Han, W. Song, G. Liu, Z. Li, P. Yang, and Y. Qu, "Improving cellulase productivity of Penicillium oxalicum RE-10 by repeated fed-batch fermentation strategy," Bioresource Technology, vol. 227, pp. 155-163, 2017.

[20] M. Rubeena, K. Neethu, S. Sajith et al., "Lignocellulolytic activities of a novel strain of Trichoderma harzianum," Advances in Bioscience and Biotechnology, vol. 4, pp. 212-221, 2013.

[21] A. L. Grigorevski-Lima, F. N. M. Da Vinha, D. T. Souza et al., "Aspergillus fumigatus thermophilic and acidophilic endoglucanases," Applied Biochemistry and Biotechnology, vol. 155, no. 1-3, pp. 321-329, 2009. 
[22] J. P. Andrade, A. S. D. R. Bispo, P. A. S. Marbach, and R. P. Do Nascimento, "Production and partial characterization of cellulases from Trichoderma sp. IS-05 isolated from Sandy Coastal plains of Northeast Brazil," Enzyme Research, vol. 2011, Article ID 167248, 7 pages, 2011.

[23] P. D. S. Delabona, C. S. Farinas, M. R. da Silva, S. F. Azzoni, and J. G. D. C. Pradella, "Use of a new Trichoderma harzianum strain isolated from the Amazon rainforest with pretreated sugar cane bagasse for on-site cellulase production," Bioresource Technology, vol. 107, pp. 517-521, 2012.

[24] C. Y. Turenne, S. E. Sanche, D. J. Hoban, J. A. Karlowsky, and A. M. Kabani, "Rapid identification of fungi by using the ITS2 genetic region and an automated fluorescent capillary electrophoresis system," Journal of Clinical Microbiology, vol. 37, no. 6, pp. 1846-1851, 1999.

[25] C. L. Schoch, K. A. Seifert, S. Huhndorf et al., "Nuclear ribosomal internal transcribed spacer (ITS) region as a universal DNA barcode marker for fungi," Proceedings of the National Acadamy of Sciences of the United States of America, vol. 109, no. 27, pp. 6241-6246, 2012.

[26] M. Shahriarinour, M. N. A. Wahab, R. Mohamad, S. Mustafa, and A. B. Ariff, "Effect of medium composition and cultural condition on cellulase production by Aspergillus terreus," African Journal of Biotechnology, vol. 10, no. 38, pp. 7459-7467, 2011.

[27] D. B. Archer and J. F. Peberdy, "The molecular biology of secreted enzyme production by fungi," Critical Reviews in Biotechnology, vol. 17, no. 4, pp. 273-306, 1997.

[28] R. Soni, A. Nazir, and B. S. Chadha, "Optimization of cellulase production by a versatile Aspergillus fumigatus fresenius strain (AMA) capable of efficient deinking and enzymatic hydrolysis of Solka floc and bagasse," Industrial Crops and Products, vol. 31, no. 2, pp. 277-283, 2010.

[29] S. P. Gautam, P. S. Bundela, A. K. Pandey, J. Khan, M. K. Awasthi, and S. Sarsaiya, "Optimization for the production of cellulase enzyme from Municipal solid waste residue by two novel cellulolytic fungi," Biotechnology Research International, pp. 1-8, 2011.

[30] M. Sohail, R. Siddiqi, A. Ahmad, and S. A. Khan, "Cellulase production from Aspergillus niger MS82: effect of temperature and pH," New Biotechnology, vol. 25, no. 6, pp. 437-441, 2009.

[31] S. Ahmed, A. Bashir, H. Saleem, M. Saadia, and A. Jamil, "Production and purification of cellulose-degrading enzymes from a filamentous fungus Trichoderma harzianum," Pakistan Journal of Botany, vol. 41, no. 3, pp. 1411-1419, 2009.

[32] A. Das, T. Paul, S. K. Halder et al., "Study on regulation of growth and biosynthesis of cellulolytic enzymes from newly isolated Aspergillus fumigatus ABK9," Polish Journal of Microbiology, vol. 62, no. 1, pp. 31-43, 2013.

[33] S. Shafique, R. Bajwa, and S. Shafique, "Cellulase biosynthesis by selected Trichoderma species," Pakistan Journal of Botany, vol. 41, no. 2, pp. 907-916, 2009.

[34] N. Sarkar and K. Aikat, "Aspergillus fumigatus NITDGPKA3 provides for increased cellulase production," International Journal of Chemical Engineering, vol. 2014, 9 pages, 2014.

[35] V. V. Gilna and K. M. Khaleel, "Cellulase enzyme activity of Aspergillus fumigatus from mangrove soil on lignocellulosic substrate," Recent Research in Science and Technology, vol. 3, no. 1, pp. 132-134, 2011.

[36] G. E. Aboul-Fotouh, G. M. El-Garhy, H. H. Azzaz, A. M. Abd El-Mola, and G. A. Mousa, "Fungal cellulase production optimisation and its utilisation in Goat's relations degradation," Asian Journal of Animal and Veterinary Advances, vol. 11, no. 12, pp. 824-831, 2016.

[37] T. Ncube, R. L. Howard, E. K. Abotsi, E. L. J. van Rensburg, and I. Ncube, "Jatropha curcas seed cake as substrate for production of xylanase and cellulase by Aspergillus niger FGSCA733 in solidstate fermentation," Industrial Crops and Products, vol. 37, no. 1, pp. 118-123, 2012.

[38] J. C. Stewart and J. B. Parry, "Factors influencing the production of cellulase by Aspergillus fumigatus (Fresenius)," Journal of General Microbiology, vol. 125, no. 1, pp. 33-39, 1981.

[39] H. Leghlimi, Z. Meraihi, H. Boukhalfa-Lezzar, E. Copinet, and F. Duchiron, "Production and characterization of cellulolytic activities produced by Trichoderma longibrachiatum (GHL)," African Journal of Biotechnology, vol. 12, no. 5, pp. 465-475, 2013. 


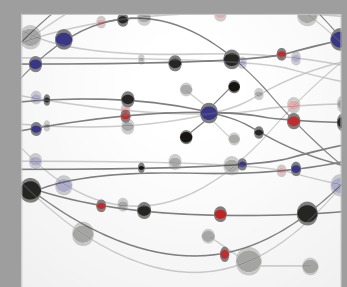

The Scientific World Journal
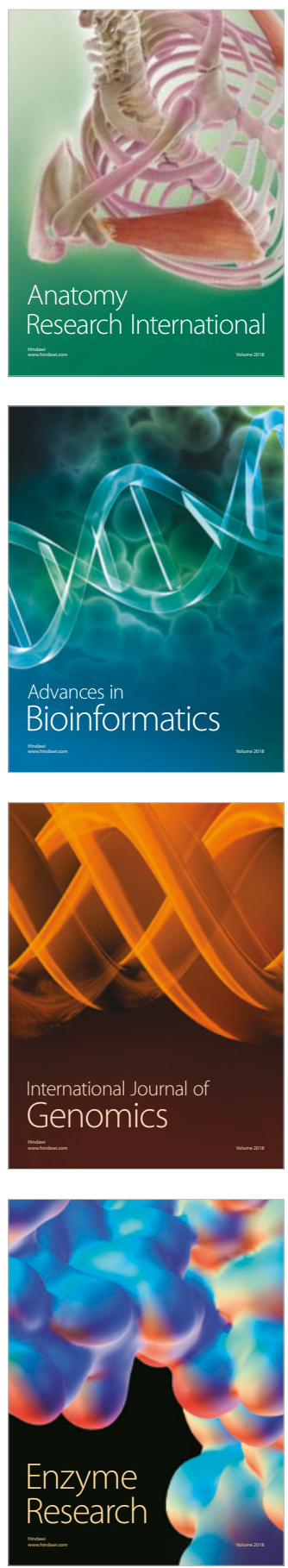
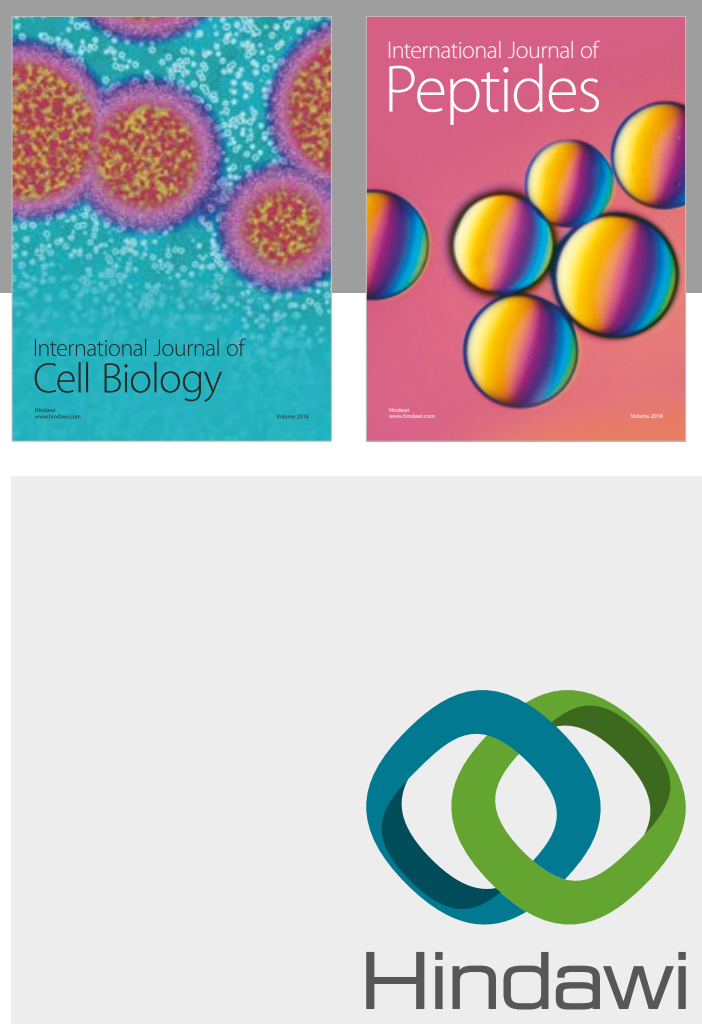

Submit your manuscripts at

www.hindawi.com
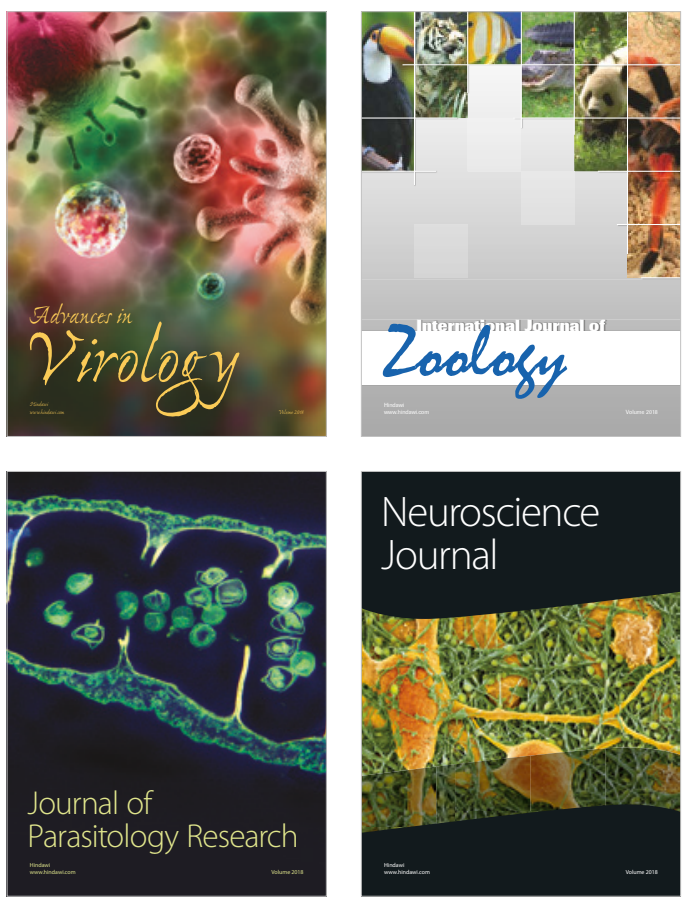
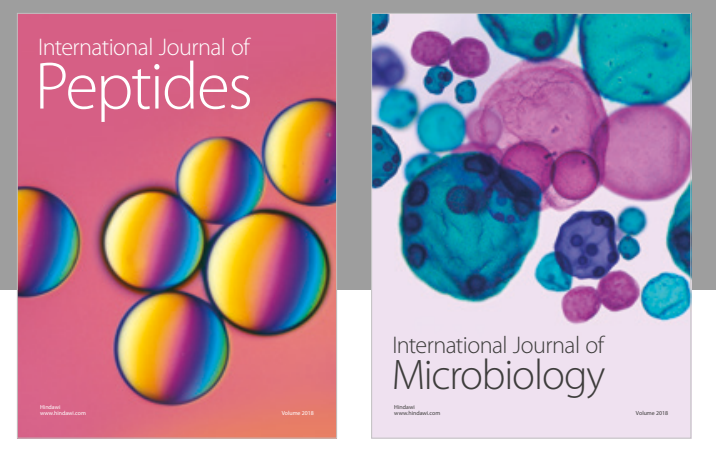

nternational Journal of Microbiology
Journal of
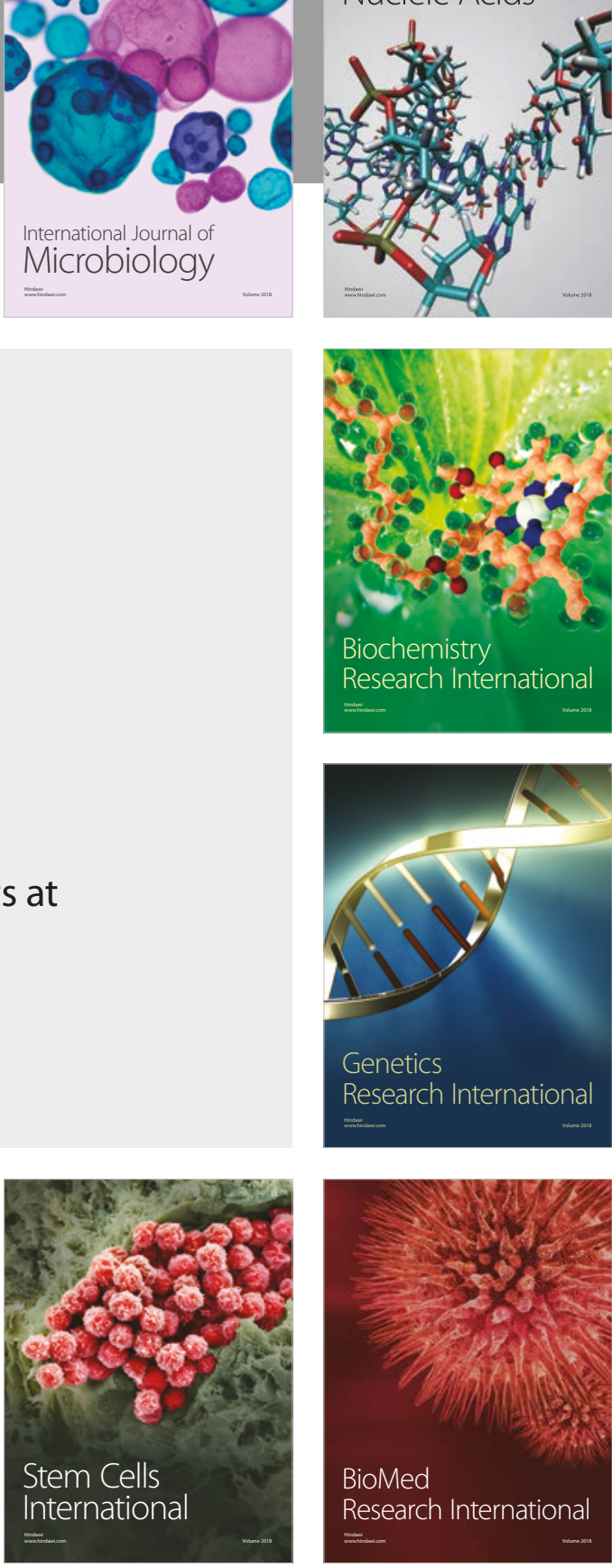
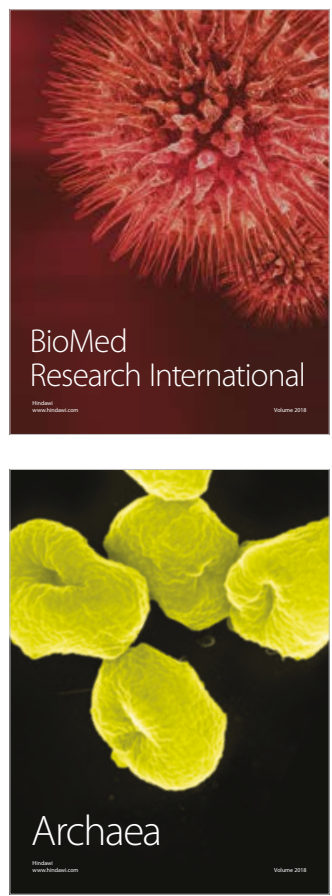